\title{
From Early Immunomodulatory Triggers to Immunosuppressive Outcome: Therapeutic Implications of the Complex Interplay Between the Wavebands of Sunlight and the Skin
}

\author{
Pablo A. Vieyra-Garcia and Peter Wolf* \\ Department of Dermatology, Medical University of Graz, Graz, Austria
}

Phototherapy is an efficient treatment for many cutaneous diseases that involve the activation of inflammatory pathways or the overgrowth of cells with aberrant phenotype. In this review, we discuss recent advances in photoimmunology, focusing on the effects of UV-based therapies currently used in dermatology. We describe the molecular responses to the main forms of photo(chemo)therapy such as UVB, UVA-1, and PUVA that include the triggering of apoptotic or immunosuppressive pathways and help to clear diseased skin. The early molecular response to UV involves DNA photoproducts, the isomerization

OPEN ACCESS

Edited by:

Herbert Hönigsmann

Medizinische Universität Wien, Austria

Reviewed by:

Günther F. L. Hofbauer,

Universität Zürich, Switzerland

Franz Trautinger,

Universitätsklinikum St. Pölten, Austria

*Correspondence:

Peter Wolf

peter.wolf@medunigraz.at

Specialty section:

This article was submitted to

Dermatology,

a section of the journa

Frontiers in Medicine

Received: 30 April 2018

Accepted: 30 July 2018

Published: 10 September 2018

Citation:

Vieyra-Garcia PA and Wolf P (2018)

From Early Immunomodulatory

Triggers to Immunosuppressive

Outcome: Therapeutic Implications of the Complex Interplay Between the

Wavebands of Sunlight and the Skin.

Front. Med. 5:232.

doi: 10.3389/fmed.2018.00232 of urocanic acid, the secretion of biophospholipids such as platelet activating factor (PAF), the activation of aryl hydrocarbon receptor and inflammasome, and vitamin D synthesis. The simultaneous and complex interaction of these events regulates the activity of the immune system both locally and systemically, resulting in apoptosis of neoplastic and/or benign cells, reduction of cellular infiltrate, and regulation of cytokines and chemokines. Regulatory T-cells and Langerhans cells, among other skin-resident cellular populations, are deeply affected by UV exposure and are therefore important players in the mechanisms of immunomodulation and the therapeutic value of UV in all its forms. We weigh the contribution of these cells to the therapeutic application of UV and how they may participate in transferring the direct impact of UV on the skin into local and systemic immunomodulation. Moreover, we review the therapeutic mechanisms revealed by clinical and laboratory animal investigations in the most common cutaneous diseases treated with phototherapy such as psoriasis, atopic dermatitis, vitiligo, and cutaneous T-cell lymphoma. Better understanding of phototherapeutic mechanisms in these diseases will help advance treatment in general and make future therapeutic strategies more precise, targeted, personalized, safe, and efficient.

Keywords: immunosupression, phototherapy, DNA damage, apoptosis, psoriasis, CTCL

Sunlight and its wavebands profoundly affect the cellular physiology and dynamics of the skin. Exposure to ultraviolet radiation (UVR) leads in the short term to sunburn and tanning and in the long term to photoaging and carcinogenesis. However, it is also well known that UVR exposure can benefit patients with certain skin diseases including psoriasis, atopic dermatitis, and cutaneous T-cell lymphoma (CTCL). The initial triggers for these diverse effects of UVR include DNA damage (1); cis-to-trans urocanic acid (UCA) isomerization (2); formation of 
active biophospholipids such as platelet activating factor (PAF) (3); and activation of aryl hydrocarbon receptor (AhR), inflammasome, and/or oxidative stress-related enzymes such as nitric oxygen synthase (NOS) (4, 5), Subsequent activation of apoptosis and mechanisms of local and systemic immunosuppression helps to counteract the effects of UV. After UV exposure, keratinocytes, melanocytes, and immune cells that reside in the skin, increase the release of cytokines such as TNF- $\alpha$, IL-6, and IL-10 (6); chemokines such as CCL27 and IL-8 (7); and metabolic products such as vitamin D, that are involved in the onset of local and systemic effects of UV in complex regulatory loops. Langerhans cells (LC) and other dendritic cells as well as regulatory T-cells (Tregs) migrate in and out of the skin, thereby coordinating a series of crucial events for the establishment of an immunosuppressive microenvironment (8).

Last year, the many efforts to define the role of visible light in the complex interplay between UVR and living organisms received recognition when JC Hall, M Rosbash, and MW Young were awarded the Nobel Prize in medicine and physiology for their work on the genes that control circadian rhythm. Their work showed that proteins such as PER or TIM in fruit flies (9) and later CLOCK in mammals (10) accumulate during the night and degrade during the day in a self-regulatory feedback loop that establishes a neuronally regulated central clock-like system. In daytime, the skin is constantly exposed to UVR. The circadian rhythm pathways affect the skin's handling of UVR effects through cooperative or autonomous processes such as vitamin $\mathrm{D}$ synthesis, reactive oxygen species (ROS) production, DNA damage, cell senescence, and immunosuppression. One example of this influence on cutaneous dynamics is seen in mice whose food intake is restricted to certain times during the circadian cycle: alterations in biological clock genes like PER2 lead to a shift of up to $10 \%$ in the cutaneous transcriptome of animals under this food intake regime (11). Additionally, genes that mitigate photo-induced DNA damage like XPA are less active during the day in mice with high nocturnal food intake, resulting in prominent accumulation of cyclobutane pyrimidine dimers (CPD) induced by diurnal experimental UVR (11). Wound healing is also controlled by the circadian cycle; skin injuries suffered during the day heal faster than those suffered during the night due to a circadian control of actin polymerization regulated by CRY and PER2 proteins (12). Keratinocytes downregulate TIMP3, a metalloproteinase inhibitor linked to CLOCK upon UVR exposure, which in turn leads to an upregulation of MMP1, TNF- $\alpha$, CXCL1, and IL- 8 promoted by C/EBP (a CCAATenhancer binding protein) (13). This indicates that UVR affects tissue remodeling and inflammatory signaling pathways by modifying the transcriptional profile of keratinocytes. A recent study looking at the role of circadian proteins in psoriasis found that loss-of-function mutations in CLOCK lead to a less severe psoriatic phenotype in imiquimod-treated mice, whereas PER2 mutations lead to increased expression of IL-23R in $\gamma / \delta$ T-cells in the skin and a more severe psoriatic manifestation (14). If circadian proteins do indeed influence the severity of cutaneous diseases, then the effectiveness of phototherapy may also depend in part on circadian cycles. However, this has not yet been explored.
The physiologic reaction of the skin to UV exposure has been harnessed therapeutically. From the first attempts of Nobel laureate Niels Finsen to treat bacterial infections with UV (15) to the clinical approaches of today in which patients are exposed to UV radiation alone or in combination with photosensitizing agents (i.e., psoralens), (16) phototherapy has provided effective management of cutaneous diseases.

\section{SENSING OF UV EXPOSURE AND TRIGGERING OF IMMUNOSUPPRESSION}

\section{DNA Damage}

Insufficient DNA repair after UVR exposure leads to the accumulation of CPD, which in turn induces immunosuppression and can give rise to skin-tumorigenic gene mutations. The activation of DNA repair mechanisms is modulated in a TLR4/MyD88-dependent manner by the cleavage of the damage-recognition molecule PARP (17). The TLR4/MyD88 axis helps commit UV-exposed cells to apoptosis by activating caspase 3 (18). Experiments with TLR $4^{-/-}$mice have shown that, after UV exposure, contact hypersensitivity (CHS) responses remain intact in these animals compared to wild type mice and the lymph nodes of TLR $4^{-/-}$mice have fewer Tregs and lower production of IL-10 and TGF- $\beta$ (19). This implicates TLR4 not only in the induction of apoptosis but also in the elicitation of immunosuppression after UV exposure. We have shown that the delivery of T4 endonuclease in liposomes to UV-irradiated skin leads to decreased secretion of IL-10 and TNF- $\alpha$, suggesting that an increased DNA repair capacity can also increase resistance to UV-induced immunosuppression (Figure 1A) (6). Supplementation of IL-12 activates components of the nucleotide-excision repair complex that lower UV-induced DNA damage and prevent immunosuppression $(20,21)$. The reduced capacity for DNA repair after UV exposure in transplant patients or in vitro with immunosuppressive drugs indicate a two-way mechanism (22). Resident memory T-cells ( $\left.\mathrm{T}_{\mathrm{RM}}\right)$ may be implicated in dealing with the effects of UVB. The main function of these cells is to provide surveillance and protection. They participate in wound healing by producing IGF-1 and immunity against pathogens like Leishmania major by producing IFN- $\gamma(23,24)$. After UV exposure, $\mathrm{T}_{\mathrm{RM}}$ detect ATP release and increase the production of IL-17, leading to activation of TWEAK (an apoptosis inducer) and GADD45 (a damage-associated cell cycle arrest checkpoint protein), which in turn promote DNA repair $(25,26)$. Together, these findings highlight the tight interconnection between apoptosis and immunosuppression by means of innate and adaptive immunity and provide a rationale for UV-ameliorating therapies such as DNA repair enzyme supplementation.

\section{Urocanic Acid Trans-isomerization}

Urocanic acid is synthesized as trans-UCA from histidine in a reaction catalyzed by histidase. It accumulates in the skin at a high concentration (6 $\mathrm{nmol} / \mathrm{cm}$ in humans) and after UV absorption is isomerized into cis-UCA and contributes to UVinduced immunosuppression (Figure 1B) (2). The treatment of keratinocytes with cis-UCA leads to upregulation of several genes 


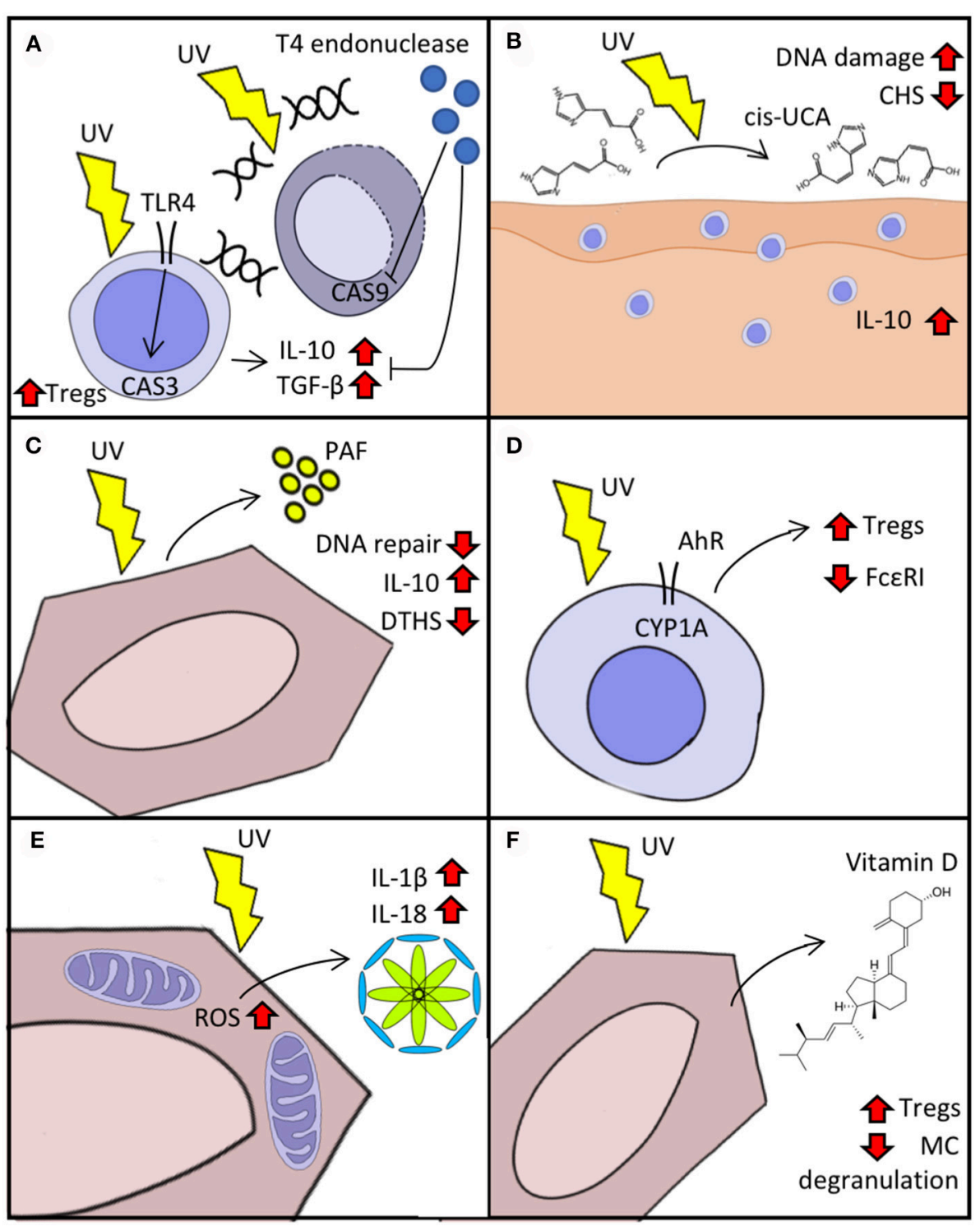

FIGURE 1 | Cellular response to UVR. (A) Immunosuppression in response to UV-induced DNA damage mediated by TLR4/MyD88. Delivery of T4 endonuclease decreases caspase (CAS) activation and the "production" of IL-10 and TGF- $\beta$. (B) Isomerization of urocanic acid (UCA) (trans to cis) after UV exposure increases IL-10 secretion and DNA damage and reduces contact hypersensitivity (CHS). (C) Keratinocyte secretion of platelet activating factor (PAF) augments immunosuppression and reduces DNA repair response to UV. (D) Activation of aryl hydrocarbon receptor (AhR) after UV reduces expression of FceRI and boosts Treg activation. (E) Reactive oxygen species (ROS) production triggered by UV exposure activates inflammasome in keratinocytes. (F) Synthesis of vitamin D after UV exposure activates Tregs and decreases IgE-mediated "mast cell (MC)" degranulation.

that resemble the transcription profile induced by exposure to UVR, whereas treatment with trans-UCA does not lead to a shift of gene expression (2). Cytokines and proteins that participate in apoptosis, cell cycle arrest, and oxidative stress are upregulated after cis-UCA treatment. Notably, cis-UCA treatment in primary keratinocytes leads to activation of NF- $\kappa \mathrm{B}$ and lipid peroxidation, suggesting a complex network of immunomodulatory-related gene transcription (27). The binding of cis-UCA and PAF to their respective receptors (5-HT2A and PAF receptor) contribute to sunburn cell formation, immune suppression, and skin cancer induction upon UVR exposure (28). Moreover, blockade of both
cis-UCA and PAF but not vitamin D reduces UV-induced DNA damage in keratinocytes of mouse skin (29).

\section{Platelet Activating Factor}

Exposure to UVR elicits the secretion of PAF by keratinocytes, which in turn promotes the migration of mast cells into draining lymph nodes where they play an important role in immunosuppression (Figure 1C) (3). After PAF stimulation, mast cells undergo epigenetic modifications that increase their responsiveness to CXCR4 agonists. These modifications are mediated by increased expression of DNMT1/3b (members of 
a DNA methyltransferase protein family) and p300 (a histone acetyltransferase) and decreased expression of HDAC2 (30). PAF also disrupts DNA-repair mechanisms upon UVR exposure by decreasing the expression of response elements such as MCPH1/BRIT-1 and ATR (31). We have reported that blockade of PAF receptor in mice treated with psoralen plus UVA (PUVA) leads to reduced IL-10 production, less delayed-type immune suppression in response to Candida albicans, and lower rates of keratinocyte apoptosis (32).

\section{Aryl Hydrocarbon Receptor}

CYP1A1 upregulation after UVR exposure implicates AhR in the skin's response to UV (4). AhR-knockout mice lack UVRinduced immunosuppression on CHS challenge (Figure 1D) (33). It has also been shown that $A h R$ participates in the induction of Tregs during T-cell differentiation in the thymus and that certain AhR agonists such as TCDD activate Tregs in the skin and gut (34-36). Moreover, AhR not only participates in Treg-mediated UVR immunosuppression but also decreases the expression of the high affinity receptor for IgE (FcERI) in LCs and upregulates immunosuppressive molecules such as IDO-1 (37). Atopic dermatitis in human patients is known to flare upon activation of FceRI in LCs (38), suggesting that therapy with UVB may act by AhR-mediated downregulation of FcERI.

\section{Reactive Oxygen Species and Inflammasome}

UV-irradiated skin shows immediate changes in a wide range of cellular processes. The biochemistry of keratinocytes and fibroblasts is rapidly redirected to produce ROS by increasing catalase activity and upregulating NOS (5). ROS activate various signaling pathways that involve stress-response factors, for example, the translocation of AP-1 and NF- $\mathrm{B}$, both of which are under the control of MAPKs that culminate in tissue remodeling and accelerated senescence (39).

ROS generation also activates inflammasome, a multiprotein intracellular oligomer responsible for initiating inflammatory responses by converting IL- $1 \beta$ and IL-18 into their active form and triggering inflammation-dependent cell death (pyroptosis) (Figure 1E) (40). UVB activates NLRP3 inflammasome in keratinocyte cells after sensing UVB-induced DNA damage (1). Yet, despite such inflammasome activation, the effects of UVR on the immune system are predominantly immunosuppressive. Upon UVB exposure, LCs emigrate from the epidermis in a process regulated by CXCR4 and $\alpha 4$-integrin $(41,42)$. After reaching draining lymph nodes, those LCs then become immunomodulatory intermediaries that promote Treg activation and produce IL-10 $(43,44)$.

\section{Vitamin D}

Vitamin D synthesis is initiated when UVB is absorbed by 7dehydrocholesterol and converted to previtamin D3, which is then later converted to vitamin D3 (Figure 1F) (45). Most cells in the body express vitamin D receptor; hence, this molecule plays a role in numerous cellular processes including cell differentiation, cell growth inhibition, and immunomodulation (46). In vitro stimulation of mast cells with vitamin D suppresses IgE-mediated degranulation, while epicutaneous vitamin D administration reduces the magnitude of skin swelling in an IgE-mediated cutaneous anaphylaxis animal model (47). By promoting vitamin D3 synthesis and causing DNA damage such as CPD and 6-4PPs, UVB plays a dual role in carcinogenesis. For example, Ptch1deficient mice are unable to produce vitamin $\mathrm{D}$ and demonstrate accelerated basal cell carcinoma-like tumor formation when exposed to UVR; this effect is reversed in vivo by exogenous supplementation of vitamin D (48). We have shown that polymorphic light eruption (PLE) patients have low levels of vitamin $\mathrm{D}$ in serum, however, prophylactic UVB treatment ameliorates PLE symptoms and increases vitamin D serum levels (49). A clinical trial evaluating the preventive properties of calcipotriol (a vitamin D analog) in 13 PLE patients showed that, 1 week of topical treatment with calcipotriol reduced the photoprovocative effect of simulated sun exposure and decreased severity disease score in PLE lesional skin (50).

\section{LANGERHANS CELL AND REGULATORY T-CELLS ARE THE MAIN ORCHESTRATORS OF UV-INDUCED IMMUNOSUPPRESSION}

LCs are a subset of dendritic cells that link the innate and adaptive immune systems by their role in priming $\mathrm{T}$-cell responses upon antigen uptake. After UVR exposure, these cells migrate out of the skin and undergo changes that make them inducers of tolerance and immunosuppression (51). Compensatory mechanisms are activated after UVR exposure to repopulate the skin with LCs and rapidly recruit monocytes from blood (52). The transitory depletion of LCs is counteracted by the early recruitment of CD14 ${ }^{+}$monocytes (after $24 \mathrm{~h}$ of UVB exposure) and subsequent mobilization of two inflammatory subsets of dendritic cells $\left(\mathrm{CD} 1 \mathrm{a}^{\text {low }} \mathrm{CD} 207^{-}\right.$and $\mathrm{CD} 1{ }^{\text {low }} \mathrm{CD} 207^{+}$ at day 1 and 4 respectively) from blood circulating cells (53). Cells of the CD11b-type Langerin ${ }^{-}$phenotype are important players in the adaptive response to UVB. After irradiation, they upregulate the expression of CD86 that leads to antigen-free proliferation of Tregs and promotes the transcription of genes associated with immunotolerance (54). The skin is also populated by $\mathrm{CD}_{103^{-}}$dendritic cells that upon UVR exposure migrate into lymph nodes and induce Treg activation by the production of retinoic acid (55). Mice depleted of LCs fail to suppress CHS reactions, indicating that these cells are major players in UV induction of Tregs. This suggests that the main function of LCs is not to promote immune responses but to desensitize the skin to UV exposure (56). UVR exposure not only drives the expansion of Tregs but also restores suppressive function by inducing demethylation of the Treg genome and thereby promoting gene transcription that counteracts inflammation in skin diseases such as psoriasis $(57,58)$. Moreover, Treg numbers in skin increase by up to $50-60 \%$ after UV irradiation and remain in high numbers for 2 weeks after irradiation. Indeed, the impact of UV is not restricted to the skin; mice exposed to UV have CPD-positive cells in their lymph nodes for at least 4 days after exposure (59) and Tregs isolated from the blood of UV-exposed animals have 
TABLE 1 | Wavebands associated with key molecular events in UV-exposed tissue.

\begin{tabular}{ll}
\hline Molecular event & Causative wavebands (peak wavelength) \\
\hline CPD & UVB (300) (63) \\
8-MOP photoadducts & UVA (329 nm), (64) \\
ROS production & UVA, UVA-1, PUVA (5) \\
Urocanic acid isomerization & UVB (280-310 nm) $(65,66)$ \\
Vitamin D synthesis & UVB (297 nm) (67) \\
PAF and PAF-like molecules & UVB, UVA, PUVA (32, 68) \\
Inflammasome activation & UVB (1) \\
\hline
\end{tabular}

a CpG hypomethylation fingerprint indicating that these Tregs were exposed to light (58). It seems that the immunosuppression triggered by UVR is in fact an adaptive response to mitigate the strong reaction of the immune system to the release of damageassociated molecular patterns (DAMPs) in favor of the repair and remodeling of damaged tissue as seen in animal models of brain injury and other trauma $(60,61)$. These observations suggest that the physiological immunosuppressive response to UVB that promotes the recovery of cells and damaged tissue can also be harnessed therapeutically to inflammatory diseases in body sites not exposed to UVR and therefore not only to cutaneous diseases.

\section{HOW DOES PHOTOTHERAPY WORK?}

Photo(chemo)therapy is a first-line treatment for skin diseases of diverse etiology, including benign conditions such as psoriasis, atopic dermatitis, vitiligo, and urticaria pigmentosa (a form of mastocytosis) as well as neoplastic disorders such as mycosis fungoides. It is also used prophylactically in certain photodermatoses like PLE. Though the high efficacy of phototherapy in these diseases has long been appreciated, the exact therapeutic mechanisms have not been fully understood until now and may depend upon the type of disease for which it is prescribed. The penetration depth of UV light increases with its wavelength. Whereas most of the photons of the UVB spectrum are absorbed in the epidermis, $~ 30 \%$ of UVA photons do reach the upper layers of the dermis (62). The initial molecular events occurring after exposure to the different wavebands and treatments are depicted in Table $\mathbf{1}$ and include CPD formation, ROS production, UCA isomerization, vitamin D synthesis, PAF secretion, and inflammasome activation (32, 63-65, 67, 68). The phototherapeutic modalities, including UVB, UVA, and PUVA, are known for their proapototic and immunomodulatory properties, which may account for their therapeutic efficacy either alone or in combination (8).

In particular, PUVA depletes activated $\mathrm{CD}^{+}$cells from lesional psoriatic skin by the induction of apoptosis $(69,70)$. The majority of $\mathrm{CD}^{+}$cells produce IL-17, a cytokine with a central role in psoriasis (71). Notably, PUVA and $311 \mathrm{~nm}$ UVB suppress the IL-17/IL-23 axis in both animal models and patients (72-76). Given the major role that these cells play in psoriasis pathophysiology, phototherapy's effect on them might explain (at least partially) its efficacy. But what is the fate of these activated T-cells? Are they directly eliminated by apoptosis or are they hampered by the complex immunomodulatory effects of phototherapy? Does the induction of Tregs (triggered by redundant upstream events including DNA and membrane damage as well cis-UCA formation and AhR activation) with immunosuppressive function diminish the number or the activity of those cells in skin? This is seen in psoriasis patients in whom bath PUVA therapy restores Treg functionality (77). Along this line, we have shown that CTLA-4 blockade abolishes the therapeutic effect of PUVA in a psoriasis mouse model (72). However, the systemic effect of phototherapy on the immune system and on Tregs seems therapeutically insufficient since psoriasis (78) and CTCL (79) lesions are cleared only on exposed body sites. This suggests that phototherapy must exert an additional direct local effect on keratinocytes, LCs, and/or lymphocytes among other players in the pathophysiology of those diseases, thereby allowing a local cell-to-cell interaction (between Tregs and pro-inflammatory effector T-cells) that leads to therapeutic response. For instance, on the local level, PUVA contributes to the normalization of the mTOR pathway upregulated in psoriasis (80). The systemic effect of PUVA or UVB in this disease may be completely independent of locally active mechanisms; for instance, serotonin signaling has been shown to play a crucial role in immune suppression but not inflammation or apoptosis in PUVA-exposed skin in a mouse model (81). A controversial computational model of psoriatic epidermis indicates that apoptosis of stem and transit amplifying cells after exposure to $311 \mathrm{~nm}$ UVB alone may be sufficient to clear lesional skin, suggesting that direct keratinocyte apoptosis is a key therapeutic mechanism (82). Moreover, psoriatic lesions clinically cleared after phototherapy contain residual oligoclonal $\mathrm{T}$-cell populations that share features of $\mathrm{T}_{\mathrm{RM}}$ and are capable of producing IL-17. These cells are likely responsible for the initiation of recurrent flares in the same body locations, implying that clinical resolution after phototherapy does not depend on depletion of cells with a dysregulated phenotype (83). In any case, the difficulty inherent in evaluating the roles of direct apoptosis and immunosuppression independently of each other highlights the need to investigate and compare phototherapy against other therapeutic approaches that induce one effect or the other.

In atopic dermatitis, phototherapy may work by strengthening the skin barrier function of lesional skin, shifting the expression of epidermal proteins like filaggrin, loricrin, and involucrin (84), augmenting levels of AMPs, (85) and shifting the microbiome diversity, among other effects $(86,87)$. In vitiligo, $311 \mathrm{UVB}$ and PUVA directly stimulate the proliferation of melanocytes and by inducing Tregs help overcome the autoimmune pathophysiology of this disease by controlling cellular mediated cytotoxicity against pigment-producing cells (88). In mastocytosis, phototherapy might act by direct cytotoxicity against activated mast cells and by stabilizing mast cells, thus inhibiting them from releasing soluble proinflammatory mediators such as histamine (89). In graft vs. host disease (GVHD), the predominant mechanism of action may be immunomodulation by downregulating the activity of grafted cells against the host (90). The effect of OVB in pruritus remains entirely elusive at the moment; however, a halfside comparison 
study implied a systemic effect, since treatment reduced pruritus not only on the irradiated body half but also to an equal degree on the unirradiated side (91). UVB-induced reduction of systemic levels of pro-pruritic IL-31 may be involved (92).

In the prophylaxis of photodermatoses such as PLE, phototherapy may act by inducing melanization in the skin, increasing vitamin $\mathrm{D}$ levels, restoring the susceptibility of the skin to respond to UV by depleting LCs and allowing infiltration of neutrophils, restoring the abnormal chemotactic potential of neutrophils, and increasing the number of peripheral Tregs to overcome the impaired immunosuppressive function of these cells $(93,94)$. Moreover, recent work has indicated that mast cells play a crucial role in countering itch by inducing phototolerance after photohardening treatment with increased numbers of Tregs in blood (95-97).

The efficacy of phototherapy in the most common form of CTCL, mycosis fungoides (MF), depends on the severity of the disease and on the type of presenting lesions. UVB has a high success rate in patients with patch-stage lesions, whereas PUVA is also effective in patients with plaque- and even early tumor-stage lesions. This differential response may be attributed to the lower penetration capacity of UVB compared to UVA as used in PUVA photochemotherapy. Alternatively, PUVA may induce longer lasting photoproducts than UVB does, resulting in a sustained downstream immunosuppressive cascade. Notably, phototherapy with both PUVA or UVB is effective not only in MF but also in lymphomatoid papulosis (LyP) (98), a disease that sometimes coexists with MF and is characterized by papules and nodules with deep skin infiltration up to $1 \mathrm{~cm}$ or more; however, these light treatments only directly reach the infiltrating cells in the most superficial layers but not those in the diseased deep tissue. The immunosuppressive microenvironment induced by phototherapy in the upper layers of the skin may be sufficient to deplete infiltrating cells in LyP and/or prevent the occurrence of new lesions in this intermittent disease.

Although broad band UVB, narrow band UVB, and oral or topical PUVA lead to different photoproducts at the DNA level (CPD vs. psoralen-DNA photoadducts) and produce overlapping molecular events (such as PAF and PAF like molecules) (Table 1), they have similar downstream effects including the induction of apoptosis and the downregulation of immune responses (including the induction of Tregs locally and systemically). In contrast, exposure to UVA and UVA1 (340-400 nm) mainly leads to oxidative alterations at the DNA and membrane level and elicits cellular responses such as the induction of MMPs and collagenase, mediators that are important particularly in UVA1's therapeutic action in fibrotic skin conditions including morphea and sclerodermic chronic GVHD (99). This may be due to the downregulation of

\section{REFERENCES}

1. Hasegawa T, Nakashima M, Suzuki Y. Nuclear DNA damage-triggered NLRP3 inflammasome activation promotes UVB-induced inflammatory responses in human keratinocytes. Biochem Biophys Res Commun. (2016) 477:329-35. doi: 10.1016/j.bbrc.2016.06.106
TGF $\beta$ signaling transducers in the skin after UVA1 exposure (100).

\section{CONCLUDING REMARKS}

After more than 100 years of using simple artificial UV light therapeutically, beginning with the pioneering work of Nobel laureate Finsen in treating cutaneous tuberculosis, diverse photo(chemo)therapeutic modalities have evolved to treat a wide spectrum of skin diseases and to prevent photodermatoses. During this evolutionary process, photo(chemo)therapy has offered avenues to better understand disease and therapeutic mechanisms and provided a large body of evidence for refining therapeutic strategies in the future. In this context, our research with PUVA has led us to realize the potential role of IL-9 in psoriasis and CTCL. PUVA reduces levels of IL-9 and IL-17 in both the TGF $\beta$ transgenic and imiquimod psoriasis mouse model $(72,75)$. The blockade of IL-9 (101) or IL-17 (72) reduced the psoriatic phenotype of these mice. Meanwhile, IL-17 antibody blockers have reached the market and are currently considered the most powerful antipsoriatic treatment. And now, in light of evidence that PUVA also downregulates IL-9 in CTCL patients and that anti-IL9 treatment reduces tumor growth in a CTCL mouse model (102), IL-9 targeting has become a promising therapeutic intervention in patients with CTCL. These and other advances in the understanding of phototherapeutic mechanisms in inflammatory and neoplastic diseases will help to make therapeutic strategies more precise, targeted, personalized, safe, and efficient.

\section{AUTHOR CONTRIBUTIONS}

PV-G and PW conceived the ideas and drafted the manuscript. PV-G drafted the figure. Both authors revised and approved the final version of the manuscript for publication.

\section{FUNDING}

This work was supported by the Oesterreichische Nationalbank Anniversary Fund project no.15463 and FWF Austrian Science Fund no. W1241 to PW. PV-G was supported by the PhD program Molecular Fundamentals of Inflammation (MOLIN) from the Medical University of Graz, Austria.

\section{ACKNOWLEDGMENTS}

The authors are very grateful to Dr. H. N. Ananthaswamy, Houston, TX, for critical reading of the manuscript and to Jude Richard, Austin, TX, for editing this manuscript.

2. Gibbs NK, Tye J, Norval M. Recent advances in urocanic acid photochemistry, photobiology and photoimmunology. Photochem Photobiol Sci. (2008) 7:655-67. doi: 10.1039/b7 $17398 \mathrm{a}$

3. Chacon-Salinas R, Chen L, Chavez-Blanco AD, Limon-Flores AY, Ma Y, Ullrich SE. An essential role for platelet-activating factor in activating mast 
cell migration following ultraviolet irradiation. J Leukoc Biol. (2014) 95:13948. doi: $10.1189 / \mathrm{jlb} .0811409$

4. Navid F, Bruhs A, Schuller W, Fritsche E, Krutmann J, Schwarz T, Schwarz A. The Aryl hydrocarbon receptor is involved in UVRinduced immunosuppression. J Invest Dermatol. (2013) 133:2763-70. doi: 10.1038/jid.2013.221

5. Heck DE, Vetrano AM, Mariano TM, Laskin JD. UVB light stimulates production of reactive oxygen species: unexpected role for catalase. J Biol Chem. (2003) 278:22432-6. doi: 10.1074/jbc.C300048200

6. Wolf P, Maier H, Mullegger RR, Chadwick CA, Hofmann-Wellenhof $\mathrm{R}$, Soyer HP, et al. Topical treatment with liposomes containing T4 endonuclease $\mathrm{V}$ protects human skin in vivo from ultraviolet-induced upregulation of interleukin-10 and tumor necrosis factor-alpha. J Invest Dermatol. (2000) 114:149-56. doi: 10.1046/j.1523-1747.2000.00839.x

7. Yoshizumi M, Nakamura T, Kato M, Ishioka T, Kozawa K, Wakamatsu $\mathrm{K}$, Kimura H, Release of cytokines/chemokines and cell death in UVBirradiated human keratinocytes, HaCaT. Cell Biol Int. (2008) 32:1405-11. doi: 10.1016/j.cellbi.2008.08.011

8. Morita A. Current developments in phototherapy for psoriasis. J Dermatol. (2018) 45:287-92. doi: 10.1111/1346-8138.14213

9. Hardin PE, Hall JC, Rosbash M. Feedback of the Drosophila period gene product on circadian cycling of its messenger RNA levels. Nature (1990) 343:536-40. doi: 10.1038/343536a0

10. King DP, Zhao Y, Sangoram AM, Wilsbacher LD, Tanaka M, Antoch MP, et al. Positional cloning of the mouse circadian clock gene. Cell (1997) 89:641-53. doi: 10.1016/S0092-8674(00)80245-7

11. Wang H, van Spyk E, Liu Q, Geyfman M, Salmans ML, Kumar V, et al. Timerestricted feeding shifts the skin circadian clock and alters UVB-induced DNA damage. Cell Rep. (2017) 20:1061-72. doi: 10.1016/j.celrep.2017.07.022

12. Hoyle NP, Seinkmane E, Putker M, Feeney KA, Krogager TP, Chesham JE, et al. Circadian actin dynamics drive rhythmic fibroblast mobilization during wound healing. Sci Transl Med. (2017) 9:eaal2774. doi: 10.1126/scitranslmed.aal2774

13. Park S, Kim K, Bae IH, Lee SH, Jung J, Lee TR, Cho EG. TIMP3 is a CLOCK-dependent diurnal gene that inhibits the expression of UVBinduced inflammatory cytokines in human keratinocytes. FASEB J. (2018) 32:1510-23. doi: 10.1096/fj.201700693R

14. Ando N, Nakamura Y, Aoki R, Ishimaru K, Ogawa H, Okumura K, et al. Circadian gene clock regulates psoriasis-like skin inflammation in mice. $J$ Invest Dermatol. (2015) 135:3001-8. doi: 10.1038/jid.2015.316

15. Jarrett P, Scragg R. A short history of phototherapy, vitamin $\mathrm{D}$ and skin disease. Photochem Photobiol Sci. (2017) 16:283-90. doi: 10.1039/C6PP00406G

16. Ling TC, Clayton TH, Crawley J, Exton LS, Goulden V, Ibbotson S, et al. British Association of Dermatologists and British Photodermatology Group guidelines for the safe and effective use of psoralen-ultraviolet A therapy 2015. Br J Dermatol. (2016) 174:24-55. doi: 10.1111/bjd.14317

17. Harberts E, Zhou H, Fishelevich R, Liu J, Gaspari AA. Ultraviolet radiation signaling through TLR4/MyD88 constrains DNA repair and plays a role in cutaneous immunosuppression. J Immunol. (2015) 194:3127-35. doi: 10.4049/jimmunol.1402583

18. Harberts E, Fishelevich R, Liu J, Atamas SP, Gaspari AA. MyD88 mediates the decision to die by apoptosis or necroptosis after UV irradiation. Innate Immun. (2014) 20:529-39. doi: 10.1177/1753425913501706

19. Lewis W, Simanyi E, Li H, Thompson CA, Nasti TH, Jaleel T. Regulation of ultraviolet radiation induced cutaneous photoimmunosuppression by toll-like receptor-4. Arch Biochem Biophys. (2011) 508:171-7. doi: 10.1016/j.abb.2011.01.005

20. Schwarz A, Maeda A, Kernebeck K, van Steeg H, Beissert S, Schwarz T. Prevention of UV radiation-induced immunosuppression by IL12 is dependent on DNA repair. J Exp Med. (2005) 201:173-9. doi: 10.1084 /jem. 20041212

21. Schwarz A, Stander S, Berneburg M, Bohm M, Kulms D, van Steeg H, et al. Interleukin-12 suppresses ultraviolet radiation-induced apoptosis by inducing DNA repair. Nat Cell Biol. (2002) 4:26-31. doi: 10.1038/ncb717

22. Herman-Edelstein M, Rozen-Zvi B, Zingerman B, Lichtenberg S, Malachi T, Gafter U, et al. Effect of immunosuppressive drugs on DNA repair in human peripheral blood mononuclear cells. Biomed Pharmacother. (2012) 66:111-5. doi: 10.1016/j.biopha.2011.11.008

23. Toulon A, Breton L, Taylor KR, Tenenhaus M, Bhavsar D, Lanigan C, et al. A role for human skin-resident T cells in wound healing. J Exp Med. (2009) 206:743-50. doi: 10.1084/jem.20081787

24. Hanson C, Lyden E, Nelson A, Thoene M, Wagner J, Wu A, et al. Response of vitamin $\mathrm{D}$ binding protein and free vitamin $\mathrm{D}$ concentrations to vitamin D supplementation in hospitalized premature infants. J Pediatr Endocrinol Metab. (2015) 28:1107-14. doi: 10.1515/jpem-2015-0089

25. MacLeod AS, Rudolph R, Corriden R, Ye I, Garijo O, Havran WL. Skin-resident $\mathrm{T}$ cells sense ultraviolet radiation-induced injury and contribute to DNA repair. J Immunol. (2014) 192:5695-702. doi: 10.4049/jimmunol.1303297

26. Hildesheim J, Bulavin DV, Anver MR, Alvord WG, Hollander MC, Vardanian L, et al. Gadd45a protects against UV irradiation-induced skin tumors, and promotes apoptosis and stress signaling via MAPK and p53. Cancer Res. (2002) 62:7305-15.

27. Kaneko K, Smetana-Just U, Matsui M, Young AR, John S, Norval M, et al. cisUrocanic acid initiates gene transcription in primary human keratinocytes. $J$ Immunol. (2008) 181:217-24. doi: 10.4049/jimmunol.181.1.217

28. Sreevidya CS, Khaskhely NM, Fukunaga A, Khaskina P, Ullrich SE. Inhibition of photocarcinogenesis by platelet-activating factor or serotonin receptor antagonists. Cancer Res. (2008) 68:3978-84. doi: 10.1158/0008-5472.CAN-07-6132

29. Sreevidya CS, Fukunaga A, Khaskhely NM, Masaki T, Ono R, Nishigori $\mathrm{C}$, et al. Agents that reverse UV-Induced immune suppression and photocarcinogenesis affect DNA repair. J Invest Dermatol. (2010) 130:142837. doi: 10.1038/jid.2009.329

30. Damiani E, Puebla-Osorio N, Gorbea E, Ullrich SE. Platelet-activating factor induces epigenetic modifications in human mast cells. J Invest Dermatol. (2015) 135:3034-40. doi: 10.1038/jid.2015.336

31. Puebla-Osorio N, Damiani E, Bover L, Ullrich SE. Platelet-activating factor induces cell cycle arrest and disrupts the DNA damage response in mast cells. Cell Death Dis. (2015) 6:e1745. doi: 10.1038/cddis.2015.115

32. Wolf P, Nghiem DX, Walterscheid JP, Byrne S, Matsumura Y, Matsumura $\mathrm{Y}$, et al. Platelet-activating factor is crucial in psoralen and ultraviolet Ainduced immune suppression, inflammation, and apoptosis. Am J Pathol. (2006) 169:795-805. doi: 10.2353/ajpath.2006.060079

33. Jux B, Kadow S, Esser C. Langerhans cell maturation and contact hypersensitivity are impaired in aryl hydrocarbon receptor-null mice. J Immunol. (2009) 182:6709-17. doi: 10.4049/jimmunol. 0713344

34. Quintana FJ, Basso AS, Iglesias AH, Korn T, Farez MF, Bettelli E, et al. Control of $\mathrm{T}(\mathrm{reg})$ and $\mathrm{T}(\mathrm{H}) 17$ cell differentiation by the aryl hydrocarbon receptor. Nature (2008) 453:65-71. doi: 10.1038/nature06880

35. Ye J, Qiu J, Bostick JW, Ueda A, Schjerven H, Li S, et al. The aryl hydrocarbon receptor preferentially marks and promotes gut regulatory $\mathrm{T}$ cells. Cell Rep. (2017) 21:2277-90. doi: 10.1016/j.celrep.2017.10.114

36. Gandhi R, Kumar D, Burns EJ, Nadeau M, Dake B, Laroni A, et al. Quintana FJ, Activation of the aryl hydrocarbon receptor induces human type 1 regulatory T cell-like and Foxp3(+) regulatory T cells. Nat Immunol. (2010) 11:846-53. doi: 10.1038/ni.1915

37. Koch S, Stroisch TJ, Vorac J, Herrmann N, Leib N, Schnautz S, et al. AhR mediates an anti-inflammatory feedback mechanism in human Langerhans cells involving FcepsilonRI and IDO. Allergy (2017) 72:1686-93. doi: $10.1111 /$ all. 13170

38. Semper AE, Heron K, Woollard AC, Kochan JP, Friedmann PS, Church MK, et al. Surface expression of Fc epsilon RI on Langerhans' cells of clinically uninvolved skin is associated with disease activity in atopic dermatitis, allergic asthma, and rhinitis. J Allergy Clin Immunol. (2003) 112:411-9. doi: 10.1067/mai.2003.1626

39. Carlson ME, Silva HS, Conboy IM. Aging of signal transduction pathways, and pathology. Exp Cell Res. (2008) 314:1951-61. doi: 10.1016/j.yexcr.2008.03.017

40. Martinon F. Dangerous liaisons: mitochondrial DNA meets the NLRP3 inflammasome. Immunity (2012) 36:313-5. doi: 10.1016/j.immuni. 2012.03.005 
41. Villablanca EJ, Mora JR. A two-step model for Langerhans cell migration to skin-draining LN. Eur J Immunol. (2008) 38:2975-80. doi: 10.1002/eji.200838919

42. Hamakawa M, Sugihara A, Okamoto H, Horio T. Ultraviolet B radiation suppresses Langerhans cell migration in the dermis by down-regulation of alpha4 integrin. Photodermatol Photoimmunol Photomed. (2006) 22:116-23. doi: 10.1111/j.1600-0781.2006.00187.x

43. Schwarz A, Navid F, Sparwasser T, Clausen BE, Schwarz T. In vivo reprogramming of $\mathrm{UV}$ radiation-induced regulatory $\mathrm{T}$-cell migration to inhibit the elicitation of contact hypersensitivity. J Allergy Clin Immunol. (2011) 128:826-33. doi: 10.1016/j.jaci.2011.06.005

44. Yoshiki R, Kabashima K, Sakabe J, Sugita K, Bito T, Nakamura M, et al. The mandatory role of IL-10-producing and OX40 ligand-expressing mature Langerhans cells in local UVB-induced immunosuppression. J Immunol. (2010) 184:5670-7. doi: 10.4049/jimmunol.0903254

45. Wacker M, Holick MF. Sunlight and Vitamin D: A global perspective for health. Dermatoendocrinology (2013) 5:51-108. doi: 10.4161/derm.24494

46. Pike JW, Meyer MB. The vitamin D receptor: new paradigms for the regulation of gene expression by 1,25-dihydroxyvitamin $\mathrm{D}(3)$. Endocrinol Metab Clin North Am. (2010) 39:255-69. doi: 10.1016/j.ecl.2010.02.007

47. Yip KH, Kolesnikoff N, Yu C, Hauschild N, Taing H, Biggs L, et al. Mechanisms of vitamin $\mathrm{D}(3)$ metabolite repression of IgE-dependent mast cell activation. J Allergy Clin Immunol. (2014) 133:1356-64.e14. doi: 10.1016/j.jaci.2013.11.030

48. Makarova A, Wang G, Dolorito JA, Kc S, Libove E, Epstein EH Jr. Vitamin D3 produced by skin exposure to UVR inhibits murine basal cell carcinoma carcinogenesis. J Invest Dermatol. (2017) 137:2613-9. doi: 10.1016/j.jid.2017.05.037

49. Gruber-Wackernagel A, Obermayer-Pietsch B, Byrne SN, Wolf P. Patients with polymorphic light eruption have decreased serum levels of 25hydroxyvitamin-D3 that increase upon $311 \mathrm{~nm}$ UVB photohardening. Photochem Photobiol Sci. (2012) 11:1831-6. doi: 10.1039/C2PP25188D

50. Gruber-Wackernagel A, Bambach I, Legat FJ, Hofer A, Byrne SN, Quehenberger F, et al. Randomized double-blinded placebo-controlled intraindividual trial on topical treatment with a 1,25-dihydroxyvitamin $\mathrm{D}(3)$ analogue in polymorphic light eruption. Br J Dermatol. (2011) 165:152-63. doi: 10.1111/j.1365-2133.2011.10333.x

51. Meunier L, Bata-Csorgo Z, Cooper KD. In human dermis, ultraviolet radiation induces expansion of a CD36+CD11b + CD1- macrophage subset by infiltration and proliferation; CD1+ Langerhans-like dendritic antigenpresenting cells are concomitantly depleted. J Invest Dermatol. (1995) 105:782-8. doi: 10.1111/1523-1747.ep12326032

52. Chopin $M$, Seillet $C$, Chevrier $\mathrm{S}$, Wu L, Wang $\mathrm{H}$, Morse HC III, et al. Langerhans cells are generated by two distinct PU.1dependent transcriptional networks. J Exp Med. (2013) 210:2967-80. doi: 10.1084/jem.20130930

53. Achachi A, Vocanson M, Bastien P, Peguet-Navarro J, Grande S, Goujon C, et al. UV radiation induces the epidermal recruitment of dendritic cells that compensate for the depletion of Langerhans cells in human skin. J Invest Dermatol. (2015) 135:2058-67. doi: 10.1038/jid.2015.118

54. Yamazaki S, Odanaka M, Nishioka A, Kasuya S, Shime H, Hemmi H, et al. Ultraviolet B-induced maturation of CD11b-Type Langerin(-) dendritic cells controls the expansion of Foxp3(+) regulatory T cells in the skin. J Immunol. (2018) 200:119-29. doi: 10.4049/jimmunol.1701056

55. Guilliams M, Crozat K, Henri S, Tamoutounour S, Grenot P, Devilard E, et al. Skin-draining lymph nodes contain dermis-derived CD103(-) dendritic cells that constitutively produce retinoic acid and induce Foxp3(+) regulatory T cells. Blood (2010) 115:1958-68. doi: 10.1182/blood-2009-09245274

56. Schwarz A, Noordegraaf M, Maeda A, Torii K, Clausen BE, Schwarz T. Langerhans cells are required for UVR-induced immunosuppression. J Invest Dermatol. (2010) 130:1419-27. doi: 10.1038/jid.2009.429

57. Furuhashi T, Saito C, Torii K, Nishida E, Yamazaki S, Morita A. Photo(chemo)therapy reduces circulating Th17 cells and restores circulating regulatory $\mathrm{T}$ cells in psoriasis. PLoS ONE (2013) 8:e54895. doi: 10.1371/journal.pone.0054895

58. Yamazaki S, Nishioka A, Kasuya S, Ohkura N, Hemmi H, Kaisho T, et al. Homeostasis of thymus-derived Foxp $3+$ regulatory $\mathrm{T}$ cells is controlled by ultraviolet B exposure in the skin. J Immunol. (2014) 193:5488-97. doi: 10.4049/jimmunol.1400985

59. Vink AA, Strickland FM, Bucana C, Cox PA, Roza L, Yarosh DB, et al. Localization of DNA damage and its role in altered antigen-presenting cell function in ultraviolet-irradiated smice. J Exp Med. (1996) 183:1491-500. doi: 10.1084/jem.183.4.1491

60. Liesz A, Dalpke A, Mracsko E, Antoine DJ, Roth S, Zhou W, et al. DAMP signaling is a key pathway inducing immune modulation after brain injury. $J$ Neurosci. (2015) 35:583-98. doi: 10.1523/JNEUROSCI.2439-14.2015

61. Islam MN, Bradley BA, Ceredig R. Sterile post-traumatic immunosuppression. Clin Transl Immunol. (2016) 5:e77. doi: 10.1038/cti. 2016.13

62. Patra V, Laoubi L, Nicolas JF, Vocanson M, Wolf P. A perspective on the interplay of ultraviolet-radiation, skin microbiome and skin resident memory TCR $\alpha \beta+$ cells. Front Med. (2018) 5:166. doi: 10.3389/fmed.2018.00166

63. Young AR, Chadwick CA, Harrison GI, Nikaido O, Ramsden J, Potten CS. The similarity of action spectra for thymine dimers in human epidermis and erythema suggests that DNA is the chromophore for erythema. J Invest Dermatol. (1998) 111:982-8. doi: 10.1046/j.1523-1747.1998.00436.x

64. Bevilacqua PM, Edelson RL, Gasparro FP. High-performance liquid chromotography analysis of 8-methoxypsoralen monoadducts and crosslinks in lymphocytes and keratinocytes. J Invest Dermatol. (1991) 97:151-5. doi: 10.1111/1523-1747.ep12479321

65. Gibbs NK, Norval M, Traynor NJ, Wolf M, Johnson BE, Crosby J. Action spectra for the trans to cis photoisomerisation of urocanic acid in vitro and in mouse skin. Photochem Photobiol. (1993) 57:584-90. doi: 10.1111/j.1751-1097.1993.tb02338.x

66. McLoone P, Simics E, Barton A, Norval M, Gibbs NK. An action spectrum for the production of cis-urocanic acid in human skin in vivo. J Invest Dermatol. (2005) 124:1071-4. doi: 10.1111/j.0022-202X.2005.23731.x

67. MacLaughlin JA, Anderson RR, Holick MF. Spectral character of sunlight modulates photosynthesis of previtamin D3 and its photoisomers in human skin. Science (1982) 216:1001-3. doi: 10.1126/science.6281884

68. Walterscheid JP, Ullrich SE, Nghiem DX. Platelet-activating factor, a molecular sensor for cellular damage, activates systemic immune suppression. J Exp Med. (2002) 195:171-9. doi: 10.1084/jem.20011450

69. Coven TR, Walters IB, Cardinale I, Krueger JG. PUVA-induced lymphocyte apoptosis: mechanism of action in psoriasis. Photodermatol Photoimmunol Photomed. (1999) 15:22-7. doi: 10.1111/j.1600-0781.1999.tb00048.x

70. Vallat VP, Gilleaudeau P, Battat L, Wolfe J, Nabeya R, Heftler N, et al. PUVA bath therapy strongly suppresses immunological and epidermal activation in psoriasis: a possible cellular basis for remittive therapy. J Exp Med. (1994) 180:283-96. doi: 10.1084/jem.180.1.283

71. Lockshin B, Balagula Y, Merola JF. Interleukin-17, Inflammation, cardiovascular risk in patients with psoriasis. J Am Acad Dermatol. (2018) 79:345-52. doi: 10.1016/j.jaad.2018.02.040

72. Singh TP, Schon MP, Wallbrecht K, Michaelis K, Rinner B, Mayer G, et al. 8-methoxypsoralen plus ultraviolet A therapy acts via inhibition of the IL23/Th17 axis and induction of Foxp3 + regulatory T cells involving CTLA4 signaling in a psoriasis-like skin disorder. J Immunol. (2010) 184:7257-67. doi: 10.4049/jimmunol.0903719

73. Racz E, Prens EP, Kurek D, Kant M, de Ridder D, Mourits S, et al. Effective treatment of psoriasis with narrow-band UVB phototherapy is linked to suppression of the IFN and Th17 pathways. J Invest Dermatol. (2011) 131:1547-58. doi: 10.1038/jid.2011.53

74. Coimbra S, Oliveira H, Reis F, Belo L, Rocha S, Quintanilha A, et al. Interleukin (IL)-22, IL-17, IL-23, IL-8, vascular endothelial growth factor and tumour necrosis factor-alpha levels in patients with psoriasis before, during and after psoralen-ultraviolet $\mathrm{A}$ and narrowband ultraviolet $\mathrm{B}$ therapy. Br J Dermatol. (2010) 163:1282-90. doi: 10.1111/j.1365-2133.2010. 09992.x

75. Shirsath N, Wagner K, Tangermann S, Schlederer M, Ringel C, Kenner L, et al. 8-methoxypsoralen plus ultraviolet A reduces the psoriatic response to imiquimod in a murine model. Acta Derm Venereol. (2018). 98:576-84. doi: 10.2340/00015555-2905

76. Johnson-Huang LM, Suarez-Farinas M, Sullivan-Whalen M, Gilleaudeau P, Krueger JG, Lowes MA. Effective narrow-band UVB radiation therapy 
suppresses the IL-23/IL-17 axis in normalized psoriasis plaques. J Invest Dermatol. (2010) 130:2654-63. doi: 10.1038/jid.2010.166

77. Kubo R, Muramatsu S, Sagawa Y, Saito C, Kasuya S, Nishioka A, et al. BathPUVA therapy improves impaired resting regulatory $\mathrm{T}$ cells and increases activated regulatory T cells in psoriasis. J Dermatol Sci. (2017) 86:46-53. doi: 10.1016/j.jdermsci.2017.01.001

78. Wolf P, Weger W, Legat FJ, Posch-Fabian T, Gruber-Wackernagel A, Inzinger $\mathrm{M}$, et al. Treatment with 311-nm ultraviolet B enhanced response of psoriatic lesions in ustekinumab-treated patients: a randomized intraindividual trial. Br J Dermatol. (2012) 166:147-53. doi: 10.1111/j.1365-2133.2011.10616.x

79. Gilchrest BA, Parrish JA, Tanenbaum L, Haynes HA, Fitzpatrick TB. Oral methoxsalen photochemotherapy of mycosis fungoides. Cancer (1976) 38:683-9. doi: 10.1002/1097-0142(197608)38:2<683::AID-CNCR28203 $80210>3.0 . \mathrm{CO} ; 2-\mathrm{V}$

80. Shirsath N, Mayer G, Singh TP, Wolf P. 8-methoxypsoralen plus UVA (PUVA) therapy normalizes signalling of phosphorylated component of mTOR pathway in psoriatic skin of K5.hTGFbetal transgenic mice. Exp Dermatol. (2015) 24:889-91. doi: 10.1111/exd.12779

81. Wolf P, Byrne SN, Limon-Flores AY, Hoefler G, Ullrich SE. Serotonin signalling is crucial in the induction of PUVA-induced systemic suppression of delayed-type hypersensitivity but not local apoptosis or inflammation of the skin. Exp Dermatol. (2016) 25:537-43. doi: 10.1111/exd.12990

82. Weatherhead SC, Farr PM, Jamieson D, Hallinan JS, Lloyd JJ, Wipat A, et al. Keratinocyte apoptosis in epidermal remodeling and clearance of psoriasis induced by UV radiation. J Invest Dermatol. (2011) 131:1916-26. doi: 10.1038/jid.2011.134

83. Matos TR, O'Malley JT, Lowry EL, Hamm D, Kirsch IR, Robins HS, et al. Clinically resolved psoriatic lesions contain psoriasis-specific IL17-producing alphabeta T cell clones. J Clin Invest. (2017) 127:4031-41. doi: $10.1172 /$ JCI93396

84. Torii K, Nakamura M, Morita A. NB-UVB irradiation increases filaggrin expression in a three-dimensional human skin model. J Dermatol Sci. (2013) 70:146-7. doi: 10.1016/j.jdermsci.2013.02.007

85. Glaser R, Navid F, Schuller W, Jantschitsch C, Harder J, Schroder JM, et al. UV-B radiation induces the expression of antimicrobial peptides in human keratinocytes in vitro and in vivo. J Allergy Clin Immunol. (2009) 123:1117-23. doi: 10.1016/j.jaci.2009.01.043

86. Dotterud LK, Wilsgaard T, Vorland LH, Falk ES. The effect of UVB radiation on skin microbiota in patients with atopic dermatitis and healthy controls. Int J Circumpolar Health (2008) 67:254-60. doi: 10.3402/ijch.v67i2-3.18282

87. Patra V, Byrne SN, Wolf P. The skin microbiome: is it affected by UV-induced immune suppression? Front Microbiol. (2016) 7:1235. doi: $10.3389 /$ fmicb.2016.01235

88. Esmat S, Hegazy RA, Shalaby S, Chu-Sung Hu S, Lan CE. Phototherapy and combination therapies for vitiligo. Dermatol Clin. (2017) 35:171-92. doi: 10.1016/j.det.2016.11.008

89. Brazzelli V, Grassi S, Merante S, Grasso V, Ciccocioppo R, Bossi G, et al. Narrow-band UVB phototherapy and psoralen-ultraviolet A photochemotherapy in the treatment of cutaneous mastocytosis: a study in 20 patients. Photodermatol Photoimmunol Photomed. (2016) 32:238-46. doi: $10.1111 /$ phpp. 12248

90. Hashimoto A, Sato T, Iyama S, Yoshida M, Ibata S, Tatekoshi A, et al. Narrow-band ultraviolet $\mathrm{b}$ phototherapy ameliorates acute graft-versus-host disease of the intestine by expansion of regulatory $\mathrm{T}$ cells. PLoS ONE (2016) 11:e0152823. doi: 10.1371/journal.pone.01 52823
91. Gilchrest BA, Rowe JW, Brown RS, Steinman TI, Arndt KA. Ultraviolet phototherapy of uremic pruritus. Long-term results and possible mechanism of action. Ann Intern Med. (1979) 91:17-21. doi: 10.7326/0003-481991-1-17

92. Narbutt J, Olejniczak I, Sobolewska-Sztychny D, Sysa-Jedrzejowska A, Slowik-Kwiatkowska I, Hawro T, et al. Narrow band ultraviolet B irradiations cause alteration in interleukin-31 serum level in psoriatic patients. Arch Dermatol Res. (2013) 305:191-5. doi: 10.1007/s00403-012-1293-6

93. Gruber-Wackernagel A, Byrne SN, Wolf P. Polymorphous light eruption: clinic aspects and pathogenesis. Dermatol Clin. (2014) 32:315-34. doi: 10.1016/j.det.2014.03.012

94. Schweintzger NA, Gruber-Wackernagel A, Shirsath N, Quehenberger F, Obermayer-Pietsch B, Wolf P. Influence of the season on vitamin D levels and regulatory $\mathrm{T}$ cells in patients with polymorphic light eruption. Photochem Photobiol Sci. (2016) 15:440-6. doi: 10.1039/C5PP00398A

95. de Gruijl FR. The mastocyte: the off switch of UV itch. Exp Dermatol. (2015) 24:489-90. doi: 10.1111/exd.12742

96. Schweintzger N, Gruber-Wackernagel A, Reginato E, Bambach I, Quehenberger F, Byrne SN, et al. Levels and function of regulatory T cells in patients with polymorphic light eruption: relation to photohardening. $\mathrm{Br} \mathrm{J}$ Dermatol. (2015) 173:519-26. doi: 10.1111/bjd.13930

97. Schweintzger NA, Bambach I, Reginato E, Mayer G, Limon-Flores $\mathrm{AY}$, Ullrich SE, et al. Mast cells are required for phototolerance induction and scratching abatement. Exp Dermatol. (2015) 24:491-6. doi: $10.1111 /$ exd.12687

98. Fernandez-de-Misa R, Hernandez-Machin B, Servitje O, Valenti-Medina F, Maronas-Jimenez L, Ortiz-Romero PL, et al. First-line treatment in lymphomatoid papulosis: a retrospective multicentre study. Clin Exp Dermatol. (2018) 43:137-43. doi: 10.1111/ced.13256

99. Kreuter A, Hyun J, Skrygan M, Sommer A, Bastian A, Altmeyer $\mathrm{P}$, et al. Ultraviolet A1-induced downregulation of human betadefensins and interleukin-6 and interleukin-8 correlates with clinical improvement in localized scleroderma. Br J Dermatol. (2006) 155:600-7. doi: 10.1111/j.1365-2133.2006.07391.x

100. Gambichler T, Skrygan M, Tomi NS, Breuksch S, Altmeyer P, Kreuter A. Significant downregulation of transforming growth factor-beta signal transducers in human skin following ultraviolet-A1 irradiation. $\mathrm{Br} \mathrm{J}$ Dermatol. (2007) 156:951-6. doi: 10.1111/j.1365-2133.2007.07802.x

101. Singh TP, Schon MP, Wallbrecht K, Gruber-Wackernagel A, Wang XJ, Wolf P. Involvement of IL-9 in Th17-associated inflammation and angiogenesis of psoriasis. PLoS ONE (2013) 8:e51752. doi: 10.1371/journal.pone.0051752

102. Vieyra-Garcia PA, Wei T, Naym DG, Fredholm S, Fink-Puches R, Cerroni L, et al. STAT3/5-dependent IL9 overexpression contributes to neoplastic cell survival in mycosis fungoides. Clin Cancer Res. (2016) 22:3328-39. doi: 10.1158/1078-0432.CCR-15-1784

Conflict of Interest Statement: The authors declare that the research was conducted in the absence of any commercial or financial relationships that could be construed as a potential conflict of interest.

Copyright ( 2018 Vieyra-Garcia and Wolf. This is an open-access article distributed under the terms of the Creative Commons Attribution License (CC BY). The use, distribution or reproduction in other forums is permitted, provided the original author(s) and the copyright owner(s) are credited and that the original publication in this journal is cited, in accordance with accepted academic practice. No use, distribution or reproduction is permitted which does not comply with these terms. 